\title{
KONTRIBUSI LINGKUNGAN KELUARGA DALAM MEMBANGUN PERILAKU SEKSUAL ANAK USIA DASAR
}

\author{
Askina Nurani Syams, Istiningsih
}

Mahasiswa S2 PGMI FITK UIN Sunan Kalijaga, Dosen FITK UIN Sunan Kalijaga

Email: chaca.kina@gmail.com

\begin{abstract}
ABSTRAK
Perilaku seksual merupakan segala tingkah laku yang didorong oleh hasrat seksual yang secara alami dimiliki oleh masing-masing manusia. Namun adanya pengaruh dari berbagai lingkungan terhadap perilaku seksual anak, membuat masing-masing anak memiliki perilaku seksual yang berbeda-beda. Salah satu lingkungan yang berperan besar dalam memberikan kontribusi bagi perilaku seksual anak adalah lingkungan keluarga. Kontribusi keluarga dalam membangun perilaku seksual anak dapat dilakukan dalam bentuk: (1) Pemberian pendidikan seks bagi anak (2) Pengawasan orang tua terhadap perilaku seks anak dan (3) Perhatian orang tua terhadap kegiatan anak. Dengan memperhatikan 3 hal tersebut, perilaku seksual anak dapat dijaga sejak dini dan dapat mencegah perilaku-perilaku seksual yang seharusnya belum terjadi pada usia anak dasar.
\end{abstract}

\section{Kata Kunci: Kontribusi Keluarga, Perilaku Seksual, Usia Dasar}

\begin{abstract}
Sexual behavior is all behavior that is driven by sexual desire that is naturally owned by each human being. But the influence of various environments on child sexual behavior, making each child has different sexual behavior. One environment that plays a major role in contributing to child sexual behavior is the family environment. The contribution of the family in building the child's sexual behavior can be done in the form of: (1) Provision of sex education for the child (2) Parental supervision on child sex behavior and (3) Parental attention to children's activities. By considering these three things, the child's sexual behavior can be safeguarded early and can prevent sexual behaviors that should not have occurred at the age of the basic child.
\end{abstract}

Keywords: Family Contribution, Sexual Behavior, Basic Age

AL-BIDAYAH: Jurnal Pendidikan Dasar Islam

Volume 9, Nomor 1, Juni 2017; ISSN: 2085-0034 


\section{A. PENDAHULUAN}

Pada era modern saat ini, pembicaraan tentang seksualitas bukanlah hal yang asing untuk didengar, akan tetapi pemahaman seksualitas tidak lepas dari konteks sosial budaya yang telah ikut mengaturnya. Sebab itu, pemahaman perilaku dan orientasi seksualitas dapat berbeda dari satu budaya ke budaya lain atau dari jangka waktu satu ke jangka waktu yang lain.

Secara historis, bagaimana kita berpikir tentang seksualitas telah mengalami perubahan dari waktu ke waktu. ${ }^{79}$ Perubahan sosial mulai terlihat dalam persepsi masyarakat yang pada mulanya meyakini seks sebagai sesuatu yang tabu menjadi sesuatu yang tidak tabu lagi, terutama di daerah Bali yang tidak seperti di daerah-daerah lain pada umumnya. Perbedaan kultur dan situasi lingkungan membuat Bali sangat terbuka terhadap budaya asing. Pornografi dan perilaku seksual yang cenderung "Barat" sangat kental nuansanya, bahkan perilaku seksual sudah dapat dilihat pada anak usia dini yang mulai memasuki masa awal pubertas.

Masalah seksualitas menjadi perhatian guru serta orang tua, dan mereka sering terkejut apabila masalah itu dikaitkan dalam hubungan murid-murid dan anak-anak. Karena masalah tersebut tidak hanya menjadi perhatian kaum muda dan remaja, namun juga pada anak-anak. Adapun anak-anak, karena dorongan ingin tahu, mereka condong untuk mengetahui lebih jauh tentang masalah kelahiran, kehamilan, alat vital dan sebagainya. ${ }^{80}$

79 Gilly Andrews, Buku Ajar Kesehatan Reproduksi Wanita, (Jakarta: EGC, 2009), hlm. 3

80 Lester A. Kirkendall, Anak dan Masalah Seks, (Jakarta: Bulan Bintang, 1985), hlm. 9
Dalam beberapa kasus, dapat diketahui bahwa perkembangan seksual pada anak-anak sekolah dasarmengalamipeningkatanke tahapan seksual yang seharusnya belum dilakukan, khususnya di daerah Jembrana Bali. Dari hasil penelitian di daerah Jembrana, didapati adanya anak perempuan kelas $\mathrm{V}$ yang sudah menonton video porno pada ponsel seluler yang ia miliki, keluar berdua ketika malam Minggu hingga jam 22.00 WITA untuk berpacaran, berpose seperti akan berciuman ketika foto bersama dengan pacarnya, merayakan hari valentine dengan pacarnya dan kegiatan lain yang kurang tepat untuk dilakukan oleh anak kelas V.

Dalam sebuah berita juga disebutkan bahwa Lembaga Perlindungan Anak (LPA) Bali sebut kota Jembrana masuk zona kuning kasus anak, khususnya kasus tindak asusila bagi anak di bawah umur. Salah satu kasus melibatkan anak yang cukup menghebohkan menimpa seorang gadis cilik yang mendapat perlakuan tindak asusila yang dilakukan oleh dua pelajar pria kakak kelasnya di salah satu Sekolah Dasar di Loloan Timur Jembrana Bali. ${ }^{81}$

Tindakan-tindakan yang mengarah ke perilaku seksual yang dilakukan oleh mereka tidaklah terlepas dari adanya pengaruh lingkungan sosial mereka, baik di sekolah, masyarakat, maupun keluarga. Dalam hal ini, lingkungan keluarga sangat memberikan kontribusi yang lebih dalam membangun perilaku seksual anak, karena pihak sekolah sendiri sudah melakukan upaya untuk menjaga anak didik mereka dari hal-hal negatif tentang perilaku seksual mereka, seperti pemisahan tempat duduk antara putera dan puteri ketika di

81 Kabar Nusa, (22 November 2015), LPA Bali Sebut Jembrana Masuk Zona Kuning Kasus Perlindungan Anak, dalam http:// www.kabarnusa.com/2015/11/lpa-bali-sebutjembrana-masuk-zona.html 
kelas, adanya pelarangan bagi anak-anak untuk membawa Hp ke sekolah setelah didapati ada salah satu peserta didik kelas $\mathrm{V}$ yang ketahuan menyimpan vidio porno di hpnya, juga adanya penyuluhan dan nasihat-nasihat tentang pacaran atau pendidikan sesks secara fleksibel dari pihak sekolah terhadap anak didiknya.

Dalam perubahan sosial yang cepat ini, keluarga perlu mempertahankan keberadaannya sebagai tempat berpijak yang aman bagi anggota keluarganya, terutama bagi anak-anak. Orang tua perlu mendampingi anak dalam mengolah informasi, baik dari buku-buku, internet atau televisi, agar anak dapat menyeleksi dan mengolah informasi secara benar. ${ }^{82}$

Kurangnya pengawasan dan kontrol dari orangtua sangat mempengaruhi perkembangan perilaku seksual anak. Dimana terdapat anak yang meminta izin pada orang tua keluar malam untuk tugas kelompok, namun anak tersebut keluar untuk berpacaran dengan pasangannya dengan menggunakan pakaian seperti layaknya pakaian orang remaja, seperti rok mini dan baju ketat dan sebagainya, meskipun ketika di sekolah mereka menggunakan pakaian islami. Dan sangat disayangkan bahwa orang tua anak tersebut tidak merasa curiga dan tidak peduli ketika anaknya keluar malam menggunakan pakaian seperti itu dengan alasan tugas kelompok.

Gambaran di atas berbeda dengan gambaran anak usia V SD/MI pada umumnya. Perilaku seksual, gaya pacaran dan cara berpakaian yang cenderung untuk dilakukan oleh anak usia remaja SMP atau SMA sudah ditiru oleh mereka yang masih di bangku SD/MI. Upaya sekolah menjadikan anak didik mereka menjadi anak yang shalih shalihah tidak semua sejalan dengan apa yang mereka peroleh di rumah. Dari sinilah

82 Kusdwiratri Setiono, Psikologi Keluarga, (Bandung: Alumni, 2011), hlm. 27 terlihat adanya kontribusi lingkungan keluarga terhadap perkembangan perilaku seksual anakanak terutama ketika mereka berada di sekitar rumah.

Dariumur enam sampai sepuluh tahun, anak secara khusus belajar berpikir tentang macammacam hal dengan melihat perbedaan tingkah laku yang salah dan benar. Kesadaraanya, atau mekanisme kontrolnya, berkembang semakin baik. Dia dapat mengembangkan kapasitas untuk mengontrol emosinya, menunda kepuasan atau kesenangan. ${ }^{83}$ Pada usia ini dunia sosial anak meluas di luar keluarga, mencangkup kelompok teman, guru, dan panutan dewasa lainnya. ${ }^{84}$ Dan anak pada usia 10 tahun sebagian besar telah belajar tentang seksual dari teman mereka. ${ }^{85}$ Pada tahap inilah akan dibahas bagaimana perilaku seksual peserta didik serta bagaimana kontribusi lingkungan keluarga dalam membangun perilaku seksual anak mereka.

\section{B. PEMBAHASAN}

\section{Lingkungan Keluarga}

Lingkungan adalah segala sesuatu yang tampak dan terdapat dalam alam kehidupan yang senantiasa berkembang. Ia adalah seluruh yang ada, baik manusia maupun benda buatan manusia, atau alam yang bergerak atau tidak bergerak. Kejadiankejadian atau hal-hal yang mempunyai hubungan dengan seseorang. ${ }^{86}$

Antara lingkungan dan manusia

83 Sri Esti Wuryani D, Pendidikan Seks Keluarga, (Jakarta: Indeks, 2008), hlm. 65

84 Jess Feist, Teori Kepribadian, (Jakarta: Salemba, 2010), hlm. 302

85 Sri Esti Wuryani D, Pendidikan Seks Keluarga, ..., hlm. 67

86 Zakiyah Darajat, Ilmu Pendidikan Islam, (Jakarta: Bumi Aksara, 2008), cet. VII, hlm. 63. 
memiliki hubungan timbal balik, lingkungan mempengaruhi manusia juga mempengaruhi lingkungan sekitarnya. ${ }^{87}$ Di dalam lingkungan terjalin suatu proses sosialisasi, dimana seorang individu atau anak didik belajar tentang perilaku, kebiasaan, dan polapola kebudayaan lain. Individu juga belajar tentang keterampilan sosial (social skills) seperti berbahasa, bergaul, berpakaian, dan cara makan. Sosialisasi merupakan proses membimbing individu ke dalam dunia sosial. $^{88}$

Pada hakikatnya kehidupan anak tidak steril atau soliter, ia hidup di antara sesama manusia dan lingkungan alamnya. Dipandang dari sudut ekologi manusia, anak hidup bersama-sama manusia lainnya. Manusia secara anthropologis memiliki budaya dan mensejarah serta memiliki teknologi. Geografi di mana tempat hidupnya anak juga mewarnai karakter anak. Misalnya anak yang tinggal di pantai, di pegunungan, di desa, di kota, masing-masing mewarnai karakter pribadinya, sosial, dan bernegaranya. Di dalam kehidupan global, anak tidak bisa terhindar dari kontaknya dengan pengaruh global. Oleh karena itu, ekologi anak diwarnai oleh keluarga, teman atau ekosistem sekolah, masyarakat, alam geografinya, sejarah kebersamaanya, politik negaranya, kemajuan teknologinya, dan isu globalisasinya. ${ }^{89}$

Keluarga adalah lingkungan pendidikan pertama bagi anak-anak, yang melalui celah-celahnya anak menyerap nilai-nilai

87 Abu Ahmadi dan Nur Uhbiyati, Ilmu Pendidikan, (Jakarta: Rineka Cipta, 2001), hlm. 64.

88 Abdullah Idi, Sosiologi Pendidikan, (Jakarta: Rajawali Press, 2013), hlm. 99.

89 Istiningsih, dkk, Ekologi Pendidikan, (Deskripsi HKI C 00201500053, 2015) keterampilan, pengetahuan dan perilaku yang ada di dalamnya, ${ }^{90}$ dalam hal ini berarti keluarga akan memberikan dasar bagi perkembangan anak di kemudian hari. ${ }^{91}$

Keluarga merupakan institusi yang paling penting pengaruhnya terhadap sosialisasi manusia, ${ }^{92}$ dimana anak berinteraksi dengan ayah, ibu dan anggota keluarga lain, sehingga anak memperoleh pendidikan formal berupa kebiasaan. Kebiasaan tersebut bermacam-macam, misalkan tentang cara makan, bertutur kata, bangun pagi dan sholat subuh, kebiasaan berpuasa, kebiasaan bersedekah, kebiasaan salam sebelum berangkat, dan lainnya. Adanya interaksi dengan anggota keluarga yang lain menciptakan sosialisasi dalam keluarga, yang dalam lingkup ini disebut sosialisasi domestik. ${ }^{93}$ Dalam periode sosialisasi domestik ini, pada usia 0-5 tahun, anak dibuat siap untuk dapat timbul perasaan kekeluargaan (sense of belonging) yang dapat memberikan suatu jaminan pada anak untuk tidak terpengaruh oleh situasi-situasi yang tidak baik yang mungkin dilihatnya di luar rumah. ${ }^{94}$

Keluarga juga merupakan pemelihara suatu kebudayaan bersama, yang diperoleh pada hakikatnya dari kebudayaan umum,

90 Mantep Miharso, Pendidikan Keluarga Qur'ani, (Yogyakarta: Safiria Insani Press, 2004), hlm. 86.

91 Kusdwiratri Setiono, Psikologi Keluarga, ( Bandung: Alumni, 2011), hlm. 24

92 Nurseno, Theory and Application of Sociology, (Solo: PT. Tiga Serangkai Pustaka Mandiri, 2011), hlm. 131.

93 Moeljono Notosoedirdjo dan Latipun, Kesehatan Mental Edisi Keempat,Cetakan keenam, (Malang: UMM Pers, 2011), hlm. 205.

94 Moeljono Notosoedirdjo dan Latipun, Kesehatan Mental Edisi Keempat,...,hlm. 205. 
tetapi dalam suatu masyarakat yang kompleks masing-masing keluarga mempunyai ciriciri yang berlainan dengan keluarga lainnya. Berbedanya kebudayaan dari setiap keluarga timbul melalui komunikasi anggota-anggota keluarga yang merupakan gabungan dari pola-pola tingkah laku individu. ${ }^{95}$

Dalam tinjauan psikologi perkembangan, pandangan tentang relasi orang tua-anak pada umumnya merujuk pada teori kelekatan yang pertama kali dicetuskan oleh John Bowlby. Bowlby mengidentifikasi pengaruh perilaku pengasuhan sebagai faktor kunci dalam hubungan orang tua-anak yang dibangun sejak usia dini. Pada masa awal kehidupannya anak mengembangkan hubungan emosi yang mendalam dengan orang dewasa yang teratur merawatnya. ${ }^{96}$

Pendidikan keluarga adalah dasar dari pendidikan anak selanjutnya. Hasilhasil pendidikan anak dalam lingkungan keluarga menentukan pendidikan anak selanjutnya, baik di sekolah maupun dalam masyarakat. ${ }^{97}$ Selama anak belum dewasa, orang tua mempunyai peranan pertama atau utama bagi anak-anaknya. Untuk membawa anak kepada kedewasaan, orang tua harus memberikan contoh yang baik karena anak suka mengimitasi kepada orang tuanya. ${ }^{98}$

95 Khairuddin H, Sosiologi Keluarga, (Yogyakarta: Nur Cahaya, 1985), hlm. 13

96 Sri Lestari, Sosiologi Keluarga, (Jakarta: Kencana, 2012), hlm. 17.

97 Ngalim Purwanto, Ilmu Pendidikan Teoritis dan Praktis, (Bandung: PT Remaja RosdaKarya, 2011), hlm. 79.

98 Abdullah Idi, Sosiologi Pendidikan, ..., hlm. 91.

\section{Perilaku Seksual}

Manusia adalah makhluk yang berkembang biak dengan memiliki keturunan, hubungan seksual adalah salah satu cara untuk memiliki keturunan, tetapi istilah seksualitas kemudian berkembang menjadi norma dan batasan-batasan maupun moralitas.Seks dan seksualitas memilki arti yang berbeda, seks dapat diartikan sebagai perbedaan badani atau biologis perempuan dan laki-laki, yang sering disebut jenis kelamin. Sedangkan seksualitas menyangkut berbagai dimensi yang sangat luas, yaitu dimensi biologis, sosial, psikologis, dan kultural. ${ }^{99}$ Seksualitas juga diartikan bagaimana orang merasakan dan mengekspresikan sifat dasar dan ciri-ciri seksualnya yang khusus. ${ }^{100}$

Perilaku seksual adalah segala tingkah laku yang didorong oleh hasrat seksual, baik dengan lawan jenisnya maupun dengan sesama jenis. Dalam hal ini, perilaku seksual pada anak dapat diwujudkan dalam tingkah laku yang bermacam-macam, mulai dari perasaan tertarik sampai tingkah laku berkencan, bercumbu, dan bersenggama. Objek seksulanya bisa berupa orang lain, orang dalam khayalan atau diri sendiri. ${ }^{101}$

Tingkah laku seksual dapat diurutkan sebagai berikut; berkencan, berpegang tangan, mencium pipi, berpelukan, mencium bibir, memegang buah dada di

99 Perkumpulan Keluarga Berencana Indonesia, Pengertian Seks dan Seksualitas dalam http:// pkbi-diy.info/page id=327

100 Robert P. Masland, Apa yang Ingin Diketahui Remaja tentang Seks, (Jakarta: Bumi Aksara, 2006), hlm.29

101 Sarwono,Sarlito W, Psikologi Remaja, (Jakarta:Grafindo Persada, 2007), hlm. 142 
atas baju, memegang buah dada di balik baju, memegang alat kelamin di atas baju, memegang alat kelamin di bawah baju, melakukan senggama. ${ }^{102}$

\section{Tahan Perkembangan Seksual Anak Menurut Sigmund Freud (Teori Psikoanalisis)}

a. Periode Infantil (4-5 Tahun)

1) Fase Oral

Fase dimana anak memperoleh kesenangan melalui mulut karena mulut merupakan organ pertama yang memberikan kesenangan pada bayi. Bayi mendapatkan zat-zat nutrisi untuk mempertahankan hidup melalui aktivitas oral, tetapi selain itu, mereka juga memperoleh kesenangan dari perilaku mengisap tersebut.

Tujuan seksual dari aktivitas oral awal ini adalah untuk mengambil atau menerima objek pilihanyaitu puting susu-ke dalam tubuh bayi. Pada masa reseptif oral, bayi mempunyai nilai yang jelas terhadap objek yang memberinya kesenangan, dan kebutuhan mereka biasanya terpuaskan tanpa diganggu oleh rasa frustasi maupun kecemasan. ${ }^{103}$

Pertahanan bayi terhadap lingkungan banyak dibantu dengan tumbuhnya gigi. Pada tahap ini, mereka memasuk ke fase oral kedua, yang disebut Freud sebagai periode sadistik oral. Pada fase ini, bayi merenspon orang lain dengan

102 Sarwono,Sarlito W, Psikologi Remaja, (Jakarta: Grafindo Persada, 2003), hlm. 53

103 Jess Feist, Teori Kepribadian, ..., hlm. 45 menggigit, mengoceh, menutup mulut, tersenyum, serta menangis.

Sementara anak tumbuh besar, mulut tetap menjadi zona erogen. Pada saat mereka dewasa, mereka mampu memuaskan kebutuhan oral dalam berbagai cara, seperti mengisap permen, mengunyah permen karet, menggigit pensil, makan berlebihan, merokok, juga mengelurkan pernyataan sarkastis yang menusuk. ${ }^{104}$

2) Fase Anal

Dorongan agresif yang pada tahun pertama kehidupan terwujud dalam bentuk sadisme oral. Dorongan ini berkembang lebih utuh di tahun kedua, saat anus muncul sebagai zona yang memberikan kepuasan seksual. Periode ini ditandai dengan kepuasan yang diperoleh melalui perilaku agresif dan fungsi-fungsi pembuangan atau ekresi. Fase ini dibagi menjadi dua, yaitu anal awal dan anal akhir.

Selama periode anal awal, anak memperoleh kepuasan dari merusak atau menghilangkan objek. Pada masa ini, sifat menghancurkan dari dorongan sadistis lebih kuat dibandingkan dorongan erotis sehingga anak-anak sering kali bertindak agresif pada orang tua karena membuat mereka frustasi dengan latihan pengguanaan toilet.

Pada saat anak memasuki periode anal akhir, mereka kadang-kadang memiliki ketertarikan pada feses atau kotoran, ketertarikan yang berakar pada kesenangan erotis yang diperoleh

104 Jess Feist, Teori Kepribadian, ..., hlm. 46 
dari perilaku buang air besar. Kadangkadang anak memberikan feses mereka pada orang tua sebagai hadiah berharga. ${ }^{105}$

\section{3) Fase Falik}

Pada kira-kira tahun ke-3 atau ke-4 anak memulai tahap ketiga dari perkembangan infantil - fase falik, yaitu masa dimana wilayah genital menjadi zona erogen utama. ${ }^{106}$ Selama periode ini, energi psikis tersalur ke dalam organ-organ kemaluan dan kenikmatan diperoleh dengan melakukan manipulasi terhadap organorgan tersebut. ${ }^{107}$ Tahap ini ditandai pertama kalinya lewat dikotomi antara perkembangan pria dan wanita. Perbedaan yang Freud yakini disebabkan oleh perbedaan anatomi antara kedua jenis kelamin tersebut. ${ }^{108}$

\section{b. Periode Laten (6- 10 tahun)}

Freud meyakini bahwa pada tahun ke-4 dan ke-5 sampai masa puber, baik anak laki-laki maupun anak perempuan lazimnya, tetapi tidak selalu, mengalami masa psikoseksual yang non aktif. Fase laten ini sebagian dimunculkan oleh upaya orang tua menghukum atau mencegah aktivitas seksual. Apabila orang tua berhasil menekan aktivitas ini, maka anak akan merepresi dorongan seksual mereka dan mengarahkan energi

\footnotetext{
105 Ibid.,
}

106 Ibid., hlm. 47

107 Neil J. Salkind, Teori-Teori Perkembangan Manusia: Sejarah Kemunculan, Konsep Dasar, Analisis Komparatif, dan Aplikasi, ( Bandung: Nusa Media, 2009), hlm. 171

108 Jess Feist, Teori Kepribadian, ..., hlm. 47 psikisnya ke sekolah, teman, hobi, serta aktivitas-aktivitas nonseksual lainnya. ${ }^{109}$

Dorongan seksual tentu saja tetap ada di masa ini, hanya saja ada hambatan dari mencapai tujuan-tujuan dari dorongan tersebut. Sekarang libido yang tersublimasi muncul dalam bentuk pencapaian sosial dan kultural. Selama periode ini, anak-anak membentuk grup atau "geng", hal yang tak mungkin terjadi di masa infantil ketika dorongan seksual sepenuhnya bersifat auteorotis. ${ }^{110}$

\section{c. Periode Genital (12 tahun)}

Periode genital dimulai pada saat pubertas dan berlanjut di sepanjang hidup individu. Pada periode ini, seseorang mencapai kematangan fisiknya. Selama masa puber, kehidupan seksual seorang mempunyai sederetan perbedaan mendasar dari periode infantil. Pertama, remaja melepaskan oto-erotismenya dan mengarahkan energi seksualnya kepada orang lain dan tak lagi pada diri mereka sendiri. Kedua, di masa ini reproduksi dapat dilakukan. Ketiga, sekalipun rasa iri akan penis terus bertahan pada anak perempuan, bagi mereka, vagina kini mendapatkan status yang sama seperti penis di masa bayi. Serupa seperti pada anak perempuan, anak laki-laki melihat organ perempuan sebagai objek yang mereka cari dan bukan sebagai sumber trauma. Keempat, seluruh dorongan seksual mengalami organisasi yang lebih utuh dan komponen-komponen dorongan yang semula beroprasi secara terpisah-pisah di awal periode infantil

109 Ibid., hlm. 52

110 Ibid., hlm. 53 
kini mengalami sintesis selama masa remaja. Mulut, anus, dan wilayah yang memberikan rasa menyenangkan kini melengkapi genital, yang berkembang menjadi zona erogen yang paling penting. ${ }^{11}$

\section{Tahap Perkembangan Psikososial Anak Menurut Erik Erikson (Teori Pasca Aliran Freud)}

a. Masa Bayi

Periode ini meliputi kurang lebih setahun pertama kehidupan dan paralel dengan fase oral dalam perkembangan menurut Freud. Akan tetapi, tahapan Erikson mangadopsi fokus yang lebih luas dari tahapan oral Freud yang hanya memperhatikan terbatas pada mulut. Bagi Erikson, masa bayi adalah masa pembentukan, dimana bayi "menerima" bukan hanya melalui mulut, namun juga melalui organ indra lain. Melalui mata misalnya, bayi menerima rangsangan visual. ${ }^{112}$

\section{b. Kanak-Kanak Awal}

Periode ini pararel dengan tahap anal Freud dan meliputi kurang lebih tahun kedua dan ketiga dalam kehidupan. Berbeda dengan Freud yang menganggap anus sebagai zona yang paling memuaskan pada tahap ini, Erikson mengambil padangan yang lebih luas. Baginya, anak-anak mendapatkan kesenangan bukan hanya mengusai otot-otot sirkular yang dapat berkontraksi, namun juga menguasai fungsi tubuh lainnya, seperti buang air kecil, jalan, memegang, dan

111 Ibid.,

112 Jess Feist, Teori Kepribadian,..., hlm. 293 lain sebagainya. ${ }^{113}$

c. Usia Bermain

Periode ini meliputi waktu yang sama dengan fase falik. Sekitar usia 3 sampai 5 tahun. Erikson menyatakan bahwa selain mengidentifikasi diri dengan orang tua mereka, anak-anak usia prasekolah mengembangkan daya gerak, keterampilan berbicara, keingintahuan, imajinasi, dan kemampuan untuk menentukan tujuan. ${ }^{114}$

d. Usia Sekolah

Kosep usia sekolah meliputi perkembangan dari usia 6 tahun hingga sekitar usia 12 atau 13 tahun dan cocok dengan tahun-tahun masa laten Freud. Pada usia ini, dunia sosial anak-anak meluas di luar keluarga, mencangkup kelompok teman, guru, dan panutan dewasa lainnya. Untuk anak usia sekolah, keinginan mereka untuk mengetahui sesuatu menjadi lebih kuat dan terikat dengan usaha dasar akan kompetensi. Pada perkembangan normal, anak akan berusaha dengan rajin untuk membaca dan menulis, berburu dan memancing, atau untuk mempelajari keterampilan yang dibutuhkan oleh kultur mereka. ${ }^{115}$

Erikson setuju dengan Freud bahwa usia sekolah adalah periode latensi psikoseksual. Latensi seksual penting, karena memungkinkan anakanak mengalihkan energi mereka untuk mempelajari teknologi kultur mereka dan strategi akan interaksi sosial mereka. ${ }^{116}$

113 Ibid., hlm. 299

114 Ibid., hlm. 300-301

115 Ibid., hlm. 302

116 Jess Feist, Teori Kepribadian,..., hlm. 302 
e. Remaja

Merupakan salah satu tahap perkembangan yang paling krusial karena di akhir periode ini, seseorang harus sudah mendapat rasa ego identitas yang tetap. Walaupun ego identitas tidak dimulai dan diakhiri selama masa remaja, krisis antara identitas dan kebingungan identitas mencapai puncaknya selama tahap ini.

Erikson melihat remaja sebagai periode latensi sosial, seperti ia melihat usia sekolah sebagai periode latensi seksual. Walaupun remaja berkembang secara seksual dan kognitif, di sebagian besar masyarakat Barat mereka diperbolehkan untuk menunda komitmen jangka panjangnya terhadap suatu pekerjaan, pasangan seksual, atau filosif adaptif akan kehidupannya. Mereka diizinkan untuk mengalami berbagai cara dan untuk mencoba peran-peran serta keyakinan baru sambil mencaricari untuk mencapai rasa ego identitas. Jadi, remaja adalah fase adaptif dari perkembangan kepribadian atau periode mencoba-coba. ${ }^{117}$

\section{f. Dewasa Muda}

Dewasa muda, yaitu masa dari sekitar 19 sampai 30 tahun, tidak terlalu dibatasi oleh waktu, namun dimulai dengan adanya keintiman di awal tahapan dan perkembanga generativitas di akhir. Dewasa muda harus mengembangka genetalitas yang matang, mengalami konflik antara keintiman dan keterasingan, serta memperoleh kekuatan dasar cinta.

Genetalitas sejati dapat berkembang hanya selama dewasa muda ketika ia dibedakan dengan rasa percaya yang sama dan berbagi secara stabil kepuasan seksual dengan seorang yang dicinta. Ia merupakan pencapaian utama psikoseksual terhadap masa dewasa muda dan hanya didapati dalam hubungan intim. ${ }^{118}$

g. Dewasa

Masa dimana manusia mulai mengambil bagian dalam masyarakat dan menerima tanggung jawab dari apapun yang diberikan oleh masyarakat. Masa dewasa ditandai oleh gaya psikoseksual prokreativitas, krisis psikososial generativitas versus stagnasi, dan kekuatan dasar rasa peduli. ${ }^{119}$

h. Usia Lanjut

Usia lanjut bukan berarti seseorang tak lagi menghasilkan (generative). Prokreasi, dalam artian sempit mengahasilkan anak, mungkin sudah tidak lagi, namun orang dalam usia lanjut tetap bisa produktif dan kreatif dalam banyak cara lain. Mereka dapat menjadi kakek nenek yang merawat cucu mereka dimana salah satu gaya psikoseksual usia lanjut adalah sensualitas tergeneralisasi. ${ }^{120}$

\section{Tahap Perkembangan Kognitif Anak Menurut Jean Peaget}

Menurut peneliti, apabila seorang anak membayangkan tentang seksualitas, maka hal tersebut termasuk dalam perilaku seksual, karena objek dalam perilaku seksual tidak hanya orang lain maupun diri sendiri, tetapi juga orang dalam khayalan. Kemampuan

118 Ibid., hlm. 306

119 Jess Feist, Teori Kepribadian,...,hlm. 308

120 Ibid., hlm. 309

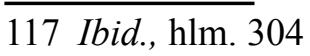


seorang anak untuk membayangkan tentang seksualitas hendaknya sesuai dengan tahapan umurnya.

Menurut teori kognitif Jean Peaget, anak umur 8-11 tahun memasuki tahap Oprasi Konkret. Tahap ini ditandai dengan perkembangan sistem pemikiran yang didasarkan pada aturan-aturan tertentu yang logis. Pada tahap ini, anak berfikir secara logis terhadap persoalan-persoalan konkret yang dihadapinya. ${ }^{121}$ Perilaku seksual yang dibayangkan oleh anak masih berdasarkan perilaku seksual yang pernah dialami. Khayalan anak masih terikat oleh waktu dan tempat, dimana anak tersebut belum saatnya membayangkan tentang perilaku seksual yang akan datang karena anak pada tahap ini belum dapat berpikir secara hipotesis.

\section{Pendidikan Seks bagi Anak-anak}

Pendidikan Seks adalah sebuah proses transfer ilmu dan sikap tentang seksualitas. ${ }^{122}$ Pendidikan seks merupakan pendidikan tentang tingkah laku yang baik sehubungan dengan masalah-masalah seks. Pendidikan seks juga diartikan sebagai semua cara pendidikan yang dapat membantu anak muda untuk menghadapi persoalan hidup yang berpusat pada naluri seks, yang kadangkadang timbul dalam bentuk tertentu. Pendidikan seks bermaksud menerangkan semua hal yang berhubungan dengan seks dan sesksualitas dalam bentuknya yang wajar; tidak terbatas pada anatomi, fisiologi, penyakit kelamin atau tingkah laku seksual

121 Paul Suparno, Teori Perkembangan Kognitif Jean Piaget, (Yogyakarta: Kanisius, 2001), hlm. 69

122 Alimatul Qibtiyah, Paradigma Pendidikan Seksualitas: Perspektif Islam: Teori dan Praktek, (Yogyakarta: Kurnia Kalam Semesta, 2006), hlm. 1 yang menyimpang, dan yang lebih penting adalah membentuk sikap serta kematangan emosional terhadap seks. ${ }^{123}$

Banyak orang tua bertanya-tanya tentang umur berapa harus dimulai pendidikan seks, mereka menyangka bahwa pendidikan tersebut tidak dimulai kecuali ketika si anak mulai bertanya tentang itu. Sebenarnya, pendidikan seks dimulai sejak kanak-kanak pertama, yang sebagian besarnya tidak lain dari gambaran tetang pendidikan seks yang tidak langsung dan tergantung kepada cara orang tua mendekati anak-anak mereka. ${ }^{124}$

Pendidikan seks memang memerlukan pengetahuan tentang seks dan seksualitas, tetapi yang paling penting adalah mengajar si anak bagaimana caranya pengetahuan itu ia gunakan dalam hidupnya. ${ }^{125}$ Pendidikan seks yang perlu diperhatikan oleh pendidik terbagi ke dalam beberapa tahap berikut ini:

a. Masa Awal Sekolah (Umur 4-5 Tahun)

Pada umur empat sampai lima tahun, anak yang normal akan berkembang kemampuannya dalam menggunakan pikiran untuk menghadapi dunianya. Meskipun hanya bereaksi terhadap lingkungannya layaknya anak kecil, dia akan mulai berfikir tentang dunia yang mengelilinginnya dan akan bertanya apa saja.

Kemampuan perkembangan bahasa anak masa prasekolah akan memungkinkan dia untuk belajar tentang

123 Sri Esti Wuryani D, Pendidikan Seks Keluarga,..., hlm. 11

124 Lester A. Kirkendall, Anak dan Masalah Seks,...,hlm. 9

125 Sri Esti Wuryani D, Pendidikan Seks Keluarga, ..., hlm. 11 
semua objek, tempat, dan orang-orang dalam dunia barunya. Anak mampu mengungkapkan pikirannya dengan bahasa atau kata-kata untuk mencoba mengerti dan memahami. ${ }^{126}$

Tergantung pada jenis latihan yang dierikan kepada anak-anak, di dalam diri mereka akan mulai terbentuk suatu perasaan moral yang berbeda. Ketika mengajarkan tentang seks, hendaknya dimasukkan nilai-nilai moral yang sesuai dengan prinsip-prinsip agama yang diyakini dalam diskusi dengan anakanak, karena menjelaskan reproduksi tanpa memasukkan dasar-dasar moral dapat berbahaya. ${ }^{127}$

Tidak semua anak yang berumur lima tahun siap menerima informasi yang sama. Bahkan mungkin akan ditemukan seorang anak yang lebih kecil ternyata lebih siap menerima suatu diskusi tentang seks daripada saudara kandungnya yang lebih tua. (juga disadari bahwa anak perempuan pada dasarnya lebih cepat matang dari pada anak laki-laki. Perkembangan emosi dan fisik anak perempuan berumur lima tahun biasanya setahun atau lebih mendahului anak lakilaki berumur lima tahun. Perbedaan ini akan berlangsung sampai tahun-tahun akhir masa remaja). ${ }^{128}$

b. Masa kanak-kanak pertengahan (Umur 6-10 tahun)

Anak-anak sekolah dasar terlihat tidak berminat terhadap seks karena

$\overline{126 \text { Ibid., hlm. } 45}$

127 Ibid., hlm. 46

128 Sri Esti Wuryani D, Pendidikan Seks Keluarga, ...,hlm. 47-48 cakrawala dunianya bertambah luas sementara eksplorasinya berkurang, dan mereka menjadi lebih pintar dalam menyembunyikan minat-minat seksual mereka. Pada masa ini belum waktunya untuk berbicara masalah seks secara spesifik-lebih baik secara umum dahulutetapi masa ini adalah saat terbaik untuk memberikan dorongan agar anak mengembangkan sikapnya. ${ }^{129}$

Menurut konsep Erik Erikson tentang perkembangan anak, anak akan merasadirinya mampu yang diperolehnya karena dia berhasil menguasai keterampilan membaca, menulis, dan berhitung. Karena dunia anak berpusat pada perasaan puas, kita dapat menambahkan pengetahuan tentang seks pada daftar keterampilannya. ${ }^{130}$ Perlu diperhatikan bahwa kerap kali masa ini merupakan masa dimana mereka lebih banyak menonton televisi sehingga setidaknya mereka rawan terhadap acaraacara yang kurang cocok bagi usia mereka sehingga perlu berhati-hati dengan memonitor apa yang mereka lihat. ${ }^{131}$

Pada umur enam tahun, anakanak secara normal menunjukkan suatu kesadaran dan minat terhadap perbedaan fisik antara laki-laki dan perempuan. Sewajarnya tingkah laku ini harusnya dicegah, namun jangan sampai membuat masalah yang lebih besar. ${ }^{132}$ Anak berumur tujuh tahun kurang berminat pada seks, tetapi beberapa eksplorasi masih
129 Ibid., hlm. 63

130 Ibid., hlm. 64

131 Ibid.,hlm., 65

132 Ibid., hlm. 66 
terjadi. ${ }^{133}$ Pada tahap ini kebanyakan energi yang pada awalnya disalurkan pada hasrat-hasrat seksual dipindahkan atau disalurkan ke perilaku-perilaku lainnya. ${ }^{134}$ Pada tahap ini hendaknya orang tua aktif memberikan nasihat-nasihat serta pembekalan tentang pendidikan seks bagi anak, seperti anak diajari tentang sopan santun meminta izin masuk rumah dan sopan santun memandang. ${ }^{135}$

Dari umur delapan sampai sepuluh tahun, anak yang normal mulai menyinggung masalah seks dan meninggalkan lelucon-lelucon yang kasar. Pada umur sembilan tahun mereka mulai berbicara tentang seks dengan teman-temannya dan mulai menggunakan istilah seksual dalam mengucapkan katakata kotor atau membuat puisi. Mereka merasa bahwa mereka akan dikagumi jika mereka belajar tentang organ seks mereka sendiri. ${ }^{136}$ Orang tua dituntut untuk lebih memberikan pengawasan bagi perkembangan seks anak pada tahap ini. Pada umur sepuluh tahun, minatnya dalam materi seks dan kebutuhan untuk tahu bertambah dramatis. ${ }^{137}$ Sebagian besar anak telah belajar dari teman mereka tentang menstruasi dan hubungan seksual, ini akan terjadi jika orang tua tidak siap memberikan informasi awal kepada mereka.

\section{Ibid., hlm. 67}

134 Neil J. Salkind, Teori-Teori Perkembangan Manusia: Sejarah Kemunculan, Konsep Dasar, Analisis Komparatif, dan Aplikasi,..., hlm. 176

135 Abdullah Nashih Ulwan, Pendidikan Anak Menurut Islam: Pendidikan Seks, ( Bandung: Remaja Rosdakarya), hlm. 1

136 Sri Esti Wuryani D, Pendidikan Seks Keluarga, ..., hlm. 67

137 Ibid., hlm. 119
Orang tua yang bijaksana sebaiknya mengungkapkan informasi ini secara singkat kepada anak ketika anak pada umur delapan atau sembilan tahun, agar anak mendapatkan informasi yang tepat. Jauh lebih baik bahwa detail tentang reproduksi seksual datang dari orang tua sendiri daripada teman-temannya yang kurang informasi. ${ }^{138}$

c. Awal Adolesens ( Umur 11-13 tahun)

Adolesen adalah masa dalam kehidupan seseorang ketika dia berubah dari anak menjadi orang dewasa. Ini adalah suatu periode secara kasar pararel dengan tahun-tahun remaja awal, tetapi kadang-kadang lebih awal lagi pada anak perempuan, yaitu umur 9 tahun. Awal adolesens dikenal juga dengan istilah "pubertas".

Tahap perkembangan ini ditandai dengan kematangan organ-organ seks yang akan dipersiapkan untuk reproduksi, menstruasi pada anak perempuan dan munculnya sperma pada anak laki-laki, sama dengan ciri-ciri seks skunder seperti tumbuhnya rambut di kemaluan dan ketiak, membesarnya payudara pada anak perempuan, dan suara yang berat pada anak laki-laki. ${ }^{139}$ Pada tahap ini orang tua hendaknya menjauhkan anak dari hal-hal yang membangkitkan birahi dan anak diajari etika bergaul dengan lawan jenis 140

Pendidikan seks tidak akan menimbulkan ingin tahu yang buruk pada anak-anak, bahkan anak-anak yang

$\overline{138 \text { Ibid., hlm. } 67}$

139 Ibid., hlm. 87

140 Abdullah Nashih Ulwan, Pendidikan Anak Menurut Islam: Pendidikan Seks, ..., hlm. 1 
mengetahui fakta-fakta tentang seks dan mereka yakin bahwa orang tua dan gurugurunya mau berbicara tentang hal tersebut secara terbuka, maka perhatiannya terhadap masalah seks akan berkurang, selama mereka mendapat jawaban yang memadai terhadap pertanyaannya, maka tidak ada alasan yang membuat mereka cemas.

Adalah wajar jika anak-anak selalu minta penjelasan agar mereka mengetahui, dan ada baiknya mereka berbuat demikian. Maka pendidikan seks tidak mematikan keinginan anak untuk mencapai tambahan pengertian, akan tetapi ia bertugas menghentikan pertanyaan yang berliku-liku. ${ }^{141}$

\section{Temuan dan Analisa Hasil Penelitian}

Berdasarkan dari teori tentang perilaku seksual, menurut penulis dalam penelitian ini perilaku seksual anak dasar kususnya untuk usia 10 tahun dapat dibagi menjadi tiga kategori, yaitu kategori ringan, sedang, dan berat. Pembagian ini berdasarkan analisis pada teori tahapan perkembangan perilaku seksual anak menurut Sigmun Freud dan Erik Erikson.

Menurut Freud, anak pada usia 10 tahun mamasuki tahap Laten, dimana libido yang tersublimasi muncul dalam bentuk pencapaian sosial dan kultural. Sedangkan menurut Erikson, usia 10 tahun memasuki periode usia sekolah dimana dunia sosial anak meluas mencangkup kelompok teman, guru, dan panutan dewasa lainnya dan keinginan mereka untuk mengetahui sesuatu menjadi lebih kuat. Contohnya mempunyai teman yang ia sukai (memiliki pacar), menyatakan

141 Abdullah Nashih Ulwan, Pendidikan Anak Menurut Islam: Pendidikan Seks, ...,hlm. 5 rasa suka terhadap teman yang ia sukai, bermain dengan mengobrol bersama baik secara langsung maupun tidak langsung, jalan-jalan bersama, berfoto-foto bersama, dan saling memberikan atau menukar hadiah bersama dengan teman yang ia sukai. Bila anak usia 10 tahun melakukan perilakuperilaku tersebut, maka menurut peneliti perilaku tersebut termasuk kategori ringan.

Berdasarkan teori Freud, anak pada usia di atas 10 tahun memasuki tahap genital, dimana anak mengarahkan energi sesksualnya pada orang lain. Sedangkan menurut Erikson, anak usia di atas 10 tahun memasuki tahap remaja, dimana seksual dan kognitifnya berkembang dan mulai mencoba-coba akan suatu hal. Bila anak usia 10 tahun melakukan perilaku pada tahap ini, seperti berpegangan tangan, mencium pipi, berpelukan, mencium leher, mencium bibir, memegang buah dada di atas atau di balik baju dan memegang alat kelamin di atas atau di balik baju, maka menurut peneliti perilaku tersebut masuk ke dalam kategori sedang. Dan bila anak usia 10 tahun melakukan perilaku seksual di atas tahap genital dan remaja, maka menurut peneliti, perilaku tersebut termasuk ke dalam kategori berat, seperti bercumbu dan melakukan senggama.

Selain itu, menurut penulis bila anak usia 10 tahun membayangkan perilaku seksual kategori ringan, maka khayalan yang dilakukan oleh anak tersebut termasuk dalam perilaku seksual kategori ringan, bila anak usia 10 tahun membayangkan perilaku seksual kategori sedang, maka khayalan yang dilakukan anak tersebut termasuk perilaku seksual kategori sedang, dan bila anak usia 10 tahun membayangkan tentang perilaku seksual kategori berat, maka khayalan yang 
dilakukan anak tersebut termasuk dalam kategori berat.

Dalam penelitian ini didapati 3 dari 6 anak usia 10 tahun perilaku seksual mereka berada pada kategori ringan dan sedang. Contoh perilaku seksual yang dilakukan mereka pada kategori ringan yaitu komunikasi tidak langsung, mengungkapkan rasa suka pada teman yang disukai dari lawan jenis, bermain dan mengganggu teman yang disukai, jalan-jalan bersama dan berfoto bersama, serta membayangkan tentang perilaku-perilaku seksual kategori ringan. Sedangkan contoh perilaku seksual kategori sedang yang ditemukan yaitu adalah dicium pada bagian leher dan disentuh dan diraba bagian dada.

Kontribusi lingkungan keluarga dalam membangun perilaku seksual anak sangat memberikan pengaruh. Dari hasil penelitian, kontribusi yang diberikan oleh lingkungan keluarga terhadap perilaku seksual anak berupa:

a. Pemberian Pendidikan Seks Bagi Anak

Pendidikan seks hendaknya diberikan pada anak sejak usia dini, karena pendidikan seks merupakan pendidikan tentangtingkah lakuyang baik sehubungan dengan masalah-masalah seks. Orang tua yang mengajarkan pendidikan seks kepada anak sejak dini dapat mencegah terjadinya penyimpangan pada perilaku seksual anak.

Dari hasil penelitian, didapati beberapa orang tua yang mengajarkan pendidikan seks pada anaknya sejak dini. Dengan pengajaran yang tepat dan pengawasan yang baik, anak mereka dapat terhindar dari perilaku seksual yang belum saatnya mereka lakukan. Dari hasil penelitian juga didapati orang tua yang sengaja menunda pendidikan seks bagi anaknya dan beranggapan bahwa anaknya belum mengerti tentang hal tersebut. Namun, penulis mendapati anak yang ditunda pemberian pendidikan seks oleh orang tuanya sudah mempunyai teman dekat dari lawan jenis yang ia sukai dan sudah melakukan perilaku seksual dalam kategori ringan.

Adanya penundaan dalam pemberian pendidikan seks dari orang tua bagi anak dapat menyebabkan anak melakukan perilaku seksual yang seharusnya belum dilakukan oleh anak tersebut, karena bisa jadi anak memperoleh informasi atau meniru perilaku seksual dari temannya atau orang yang tidak tepat. Perilaku seksual anak tersebut hendaknya segera dicegah dengan memberikan pendidikan seks pada anak sejak dini, meskipun perilaku seksual anak tersebut masih berada pada kategori ringan, namun bila orang tua terus menunda untuk memberikan pendidikan seks bagi anak tersebut, perilaku seksual anak tersebut dapat berkembang ke kategori berikutnya.

b. Pengawasan Orang Tua terhadap Perilaku Seksual Anak

Beberapa orang tua yang diteliti telah memberikan pendidikan seks bagi anak mereka berupa nasihat-nasihat. Namun, nasihat-nasihat tersebut bagaikan angin berlalu yang tidak ada hasil di dalamnya, hal ini dikarenakan kurangnya pengawasan orang tua dalam membangun perilaku seksual anak mereka.

Nasihat dan larangan yang diberikan oleh orang tua seakan tidak membuahkan hasil bagi perilaku seksual yang telah 
dilakukan anak. Dari hasil penelitian didapati beberapa informan yang orang tuanya memberikan pendididikan seks pada anak mereka namun tidak diiringi dengan pengawasan akan perilaku anak mereka. Perilaku seksual informan tersebut berada pada kategori ringan dan sedang. Hal ini juga terjadi karena beberapa sebab, yaitu tidak adanya kebersamaan orang tua dengan anak dalam kehidupan sehari-hari akibat perceraian orang tua, adanya pengaruh dari saudara atau kakak terhadap perilaku seksual anak, dan adanya pengaruh lingkungan sekitar rumah terhadap perilaku seksual anak.

Beberapa orang tua tersebut telah berusaha menjaga anak mereka dengan memberikan nasihat-nasihat seputar pendidikan seks, namun semua sebab yang mempengaruhi perilaku seksual anak di atas tidak dapat dicegah karena kurangnya pengawasan dari kedua orang tua tersebut. Bila nasihat-nasihat yang diberikan oleh orang tua kepada anak diiringin dengan pengawasan yang baik, maka nasihat-nasihat tersebut dapat terealisasikan dengan baik. Seperti yang dilakukan oleh orang tua dari salah satu informan, di mana orang tua tersebut selalu menasihati anaknya ketika hendak tidur dan ketika hendak berangkat sekolah. Nasihat ini juga dibarengin dengan pengawasan yang dilakukan oleh orang tua, seperti sering bertanya kepada guru-guru dan satpam di sekolah tentang perkembangan anaknya, selalu mengawasi gerak gerik anaknya ketika di rumah, langsung memberikan nasihat di rumah ketika mendapati hal yang kurang baik dari anaknya, dan melarang anaknya pergi jauh dari rumah.

c. Perhatian Orang Tua terhadap Kegiatan Anak

Orang tua yang memberikan kegiatan positif bagi anak, dapat mengurangi waktu luang anak untuk kegiatankegiatan yang tidak diinginkan. Dari hasil penelitian, diketahui sebagian anak yang tidak memiliki teman dekat dari lawan jenis yang ia sukai, memiliki kegiatan yang padat sejak sepulang sekolah, seperti ekstrakulikuler hingga sore, dan dilanjutkan mengaji hingga magrib.

Berlainan dengan hal tersebut, dari hasil penelitian terdapat beberapa anak yang tidak mengikuti kegiatan tersebut, cendrung memiliki lebih banyak waktu luang untuk berpegian dan bermain ke luar rumah dan menemui teman dekat dari lawan jenis yang ia sukai. Selain itu, juga terdapat anak yang tidak mengikuti ekstrakulikuler namun ia juga tidak bermain jauh dari rumahnya, waktunya banyak dihabiskan di rumah. Akan tetapi, ketika di rumah ia lebih banyak menonton sinetron remaja pada televisi, hal ini megakibatkan ia membayangkan perilaku seks dengan teman dari lawan jenis yang ia sukai tentang hal-hal yang ada di sinetron tersebut.

Jumlah keluarga serta siapa saja yang mengasuh anak dalam keluarga tersebut juga memberikan kontribusi dalam membangun perilaku seksual anak. Namun dalam penelitian ini, anak yang diasuh oleh kedua orang tuanya tidak semuanya dapat menjamin terjaganya perilaku seksual anak. Hal ini dikarenakan juga bergantung pada 
bagaiman kontribusi yang diberikan oleh kedua orang tua tersebut.

Kedua orang tua yang dapat memberikan ketiga kontribusi yang telah disebutkan sebelumnya (pemberian pendidikan seks bagi anak, pengawasan terhadap perilaku seksual anak, dan perhatian orang tua terhadap kegiatan anak) dapat memberikan hasil terjaganya perilaku seksual anak. Adapun kedua orang tua yang hanya memberikan satu atau dua kontribusi saja, seperti kedua orang tua yang hanya memberikan pendidikan seksual kepada anak mereka, namun belum memberikan pengawasan penuh terhadap perilaku seksual anak tersebut, hal ini dapat berpengaruh pada perilaku seksual anak, dimana anak tersebut perilaku seksualnya berada pada kategori ringan dan sedang.

\section{SIMPULAN}

Perilaku seksual yang dilakukan anak usia dasar kususnya umur 10 tahun dapat dibagi menjadi 3 kategori, yaitu kategori ringan, sedang, dan berat. Pembagian kategori tersebut berdasarkan hasil analisis terhadap teori Sigmun Freud dan Erik Erikson. Meskipun terdapat tiga kategori perilaku seksual, anak usia dasar atau 10 tahun cendrung melakukan perilaku seksual yang berada pada kategori ringan (komunikasi tidak langsung, mengungkapkan rasa suka pada teman yang disukai dari lawan jenis, bermain dan mengganggu teman yang disukai, jalanjalan bersama dan berfoto bersama, serta membayangkan tentang perilaku-perilaku seksual kategori ringan) dan sedang (dicium pada bagian leher dan disentuh dan diraba bagian dada).

Kontribusi keluarga dalam membangun perilaku seksual anak dapat memberikan pengaruh bagi perilaku seksual anak tersebut, kontribusi yang harus dilakukan pihak keluarga tersebut adalah pemberian pendidikan seks bagi anak, pengawasan terhadap perilaku seksual anak, dan perhatian orang tua terhadap kegiatan anak.

\section{DAFTAR PUSTAKA}

Ahmadi, Abu dan Nur Uhbiyati. 2001, Ilmu Pendidikan,Jakarta: Rineka Cipta.

Andrews, Gilly. 2009, Buku Ajar Kesehatan Reproduksi Wanita, Jakarta: EGC.

Darajat, Zakiyah. 2008, Ilmu Pendidikan Islam cet. VII, Jakarta: Bumi Aksara.

Feist, Jess. 2010, Teori Kepribadian, Jakarta: Salemba.

H, Khairuddin, 1985, Sosiologi Keluarga, Yogyakarta: Nur Cahaya.

Idi, Abdullah 2013. Sosiologi Pendidikan, Jakarta: Rajawali Press.

Istiningsih, dk. 2015, Ekologi Pendidikan, Deskripsi HKI C 00201500053.

Kabar Nusa,LPA Bali Sebut Jembrana Masuk Zona Kuning Kasus Perlindungan Anak, dalam http://www.kabarnusa. com/2015/11/lpa-bali-sebut-jembranamasuk-zona.html (22 November 2015).

Kirkendall, Lester A. 1985, Anak dan Masalah Seks, Jakarta: Bulan Bintang.

Lestari, Sri. 2012. Sosiologi Keluarga, Jakarta: Kencana.

Masland, Robert P. 2006, Apa yang Ingin Diketahui Remaja tentang Seks, Jakarta: Bumi Aksara.

Miharso, Mantep. 2004, Pendidikan Keluarga Qur'ani, Yogyakarta: Safiria Insani Press.

Notosoedirdjo, Moeljono dan Latipun. 2011. Kesehatan Mental Edisi Keempat, Cetakan Keenam, Malang: UMM Press. 
Nurseno. 2011, Theory and Application of Sociology, Solo: PT. Tiga Serangkai Pustaka Mandiri.

Perkumpulan Keluarga Berencana Indonesia, Pengertian Seks dan Seksualitas, dalamhttp://pkbi-diy.info/page id=327.

Purwanto, Ngalim. 2011, Ilmu Pendidikan Teoritis dan Praktis, Bandung: PT Remaja RosdaKarya.

Qibtiyah,Alimatul. 2006, Paradigma Pendidikan Seksualitas: Perspektif Islam: Teori dan Praktek, Yogyakarta: Kurnia Kalam Semesta.

Salkind, Neil J.2009, Teori-TeoriPerkembangan Manusia: Sejarah Kemunculan, Konsep Dasar, Analisis Komparatif, dan Aplikasi, Bandung: Nusa Media.

Sarwono, Sarlito W. 2003, Psikologi Remaja, Jakarta: Grafindo Persada. . 2007, Psikologi Remaja, Jakarta: Grafindo Persada.

Setiono, Kusdwiratri.2011, Psikologi Keluarga, Bandung: Alumni.

Suparno, Paul. 2001, Teori Perkembangan Kognitif Jean Piaget, Yogyakarta: Kanisius.

Ulwan, Abdullah Nashih. 1996, Pendidikan Anak Menurut Islam: Pendidikan Seks, Bandung: Remaja Rosdakarya.

Wuryani D, Sri Esti. 2008. Pendidikan Seks Keluarga, Jakarta: Indeks. 